\title{
過冷却水の構造と液一液相転移
}

\author{
田中秀 樹
}

\section{1. 水の過冷却状態における特異性}

水は気象など地球規模の現象から, タンパク質の安定 性や機能の発現などミクロな現象に至るまで, 我々の生 命活動に欠くことができない重要な物質である。このこ とは，水が物理化学的に特異な液体であることと密接な

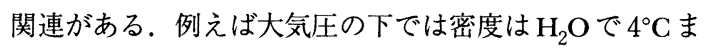
た $\mathrm{D}_{2} \mathrm{O}$ は $11^{\circ} \mathrm{C} て ゙$ 最大となる。 また通常の液体では温度 の上昇と共に圧縮し易くなり等温圧縮率は増加するが, 水では $46^{\circ} \mathrm{C}$ 付近で極小值をとり低温になっても増大す る.この特異な性質は, 液体状態における水の構造が水 の構造に似ていること,つまり液体状態でも水素結合は 切断されずに残っていることに由来するものと一般に信 じられている. 水点 $\left(T_{m}\right)$ 以下に冷却した準安定な液体 状態ではさらにそれらは顕著になる，等圧熱容量は（等 温圧縮率も）過冷却状態では非常に大きな值となり， $T_{s}=228 \mathrm{~K}$ で $C_{p}=X+A\left(T-T_{s}\right)^{-r}$ のように発散する 兆候が見られる。しかし，大気圧下では水を過冷却でき る限界は $T_{1}(233 \mathrm{~K})$ であり, これ以下では均一核生成 が起こり永への転移を避けることができない，そのため に発散が実際に起きるのかあるいは $T_{\mathrm{s}}$ でも有限であるの か，またその原因についても多くの推測がなされてきた (例えばOhmine and Tanaka, 1993). 融点に対する過冷 却が実現出来る温度 $\left(\Delta T=T_{m}-T_{1}\right)$ の比は, 一般の液 体では 0.3 程度であるが, 水は 0.14 と小さい. そこで, 水を通常の方法で急冷してガラス状態に到達することは 実験的には困難である，水は結晶になり易く無秩序な状 態を低温まで維持しにくい．特殊な方法により作った低 密度非晶質 $(\mathrm{LDA})$ 水は $T_{g}(136 \mathrm{~K})$ でガラス転移を示 し，また加熱により $T_{2}(150 \mathrm{~K})$ 付近で氷に転移する. つまり LDAは $T_{g}$ 以上 $T_{2}$ 以下では液体である。実験的に

$\overline{\text { Structure of supercooled water and liquid-liquid phase tran- }}$ sition

京都大学大学院工学研究科

于 606-01 京都市左京区吉田本町

(Hideki Tanaka, Graduate School of Engineering, Kyoto University, Yoshida-honmachi, Sakyo-ku 606-01, Japan)
は $T_{1}$ から $T_{2}$ までの水としてしか存在しない温度範囲で の準安定な液体の相変化を推測することになるので, こ のLDA と過冷却の水 (以下では Normal Water と呼ぶ) が同一の相であるかどうかは長い間論争の的であった。 これらの問題を解決するためには, 核形成が起きる以前 の非常に短い時間 $\left(10^{-6}\right.$ 秒以下) での熱力学量の測定 を行う必要がある．このためには通常の実験ではなく計 算機を用いたシミュレーションが有力な手段となってく る. 計算機シミュレーションでは, 距離と配向の関数と してあらわした水分子間の相互作用を仮定し，分子間に 働く力を計算しながら運動方程式を解いて, 分子運動の 軌跡を求める. 水分子間の相互作用の詳細は本誌におけ る河村（1995）による解説を参照されたい。計算機で取 り扱える水分子は $10^{2} \sim 10^{4}$ であり，また時間も $10^{-8}$ 秒 程度までである。

\section{2. シミュレーションから得られた過冷却水の相図}

上記の問題を解決すべく計算機シミュレーションが行 われ, 準安定状態の過冷却水の相図が提案された (Poole et al., 1992; Tanaka, $1996 \mathrm{a} \cdot \mathrm{b}$ )。ここでは, 過冷却 水に関する相平衡および構造の特徴を紹介する．最新の 相図では Normal Water-LDAの臨界点の位置が負の圧力 領域にあり， Normal Water と LDA は大気圧下では異な る相であると考えられている(図 1)。水は相転移を経 てLDAになる（LDAは $T_{\mathrm{g}}$ 以上の温度では液体）この LDA と呼ばれる相は，どのような性質を持つのであろう か? ?ず，最も簡単に計算できる系のポテンシャルエネ ルギーを図 2 に示す。ポテンシャルエネルギーのうち簡 単な温度依存性のある調和振動のエネルギーは差し引か れている. 全ての圧力下で, 温度の低下と共にポテンシ ヤルエネルギーは隇少しているが，大気圧では明らかに $213 \mathrm{~K}$ で不連続になり，大きく減少している．2000気圧 でも不連続は認められるが，そのギャップは大気圧の場 合と比較して小さくなり，また低温側にシフトしている. 一方ー2000気圧では不連続は見られず，低温ではエネ ルギーの隇少はむしろ緩やかになっている，密度に関す 


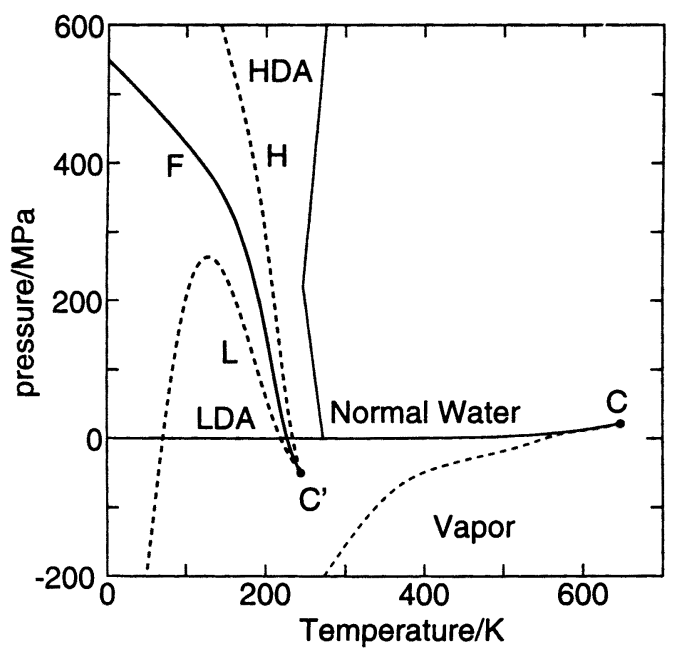

図 1 水の相図. 細線は安定相, 太線は準安定相の境界, 太い実線は共存線，破線はスピノーダル線をあらわす。 Cは気液平衡の臨界点, C’はLDAと HDAの臨界点. 1 気压で Normal Water はスピノーダル線 Lを越えた低 温側では不安定でLDAになる。

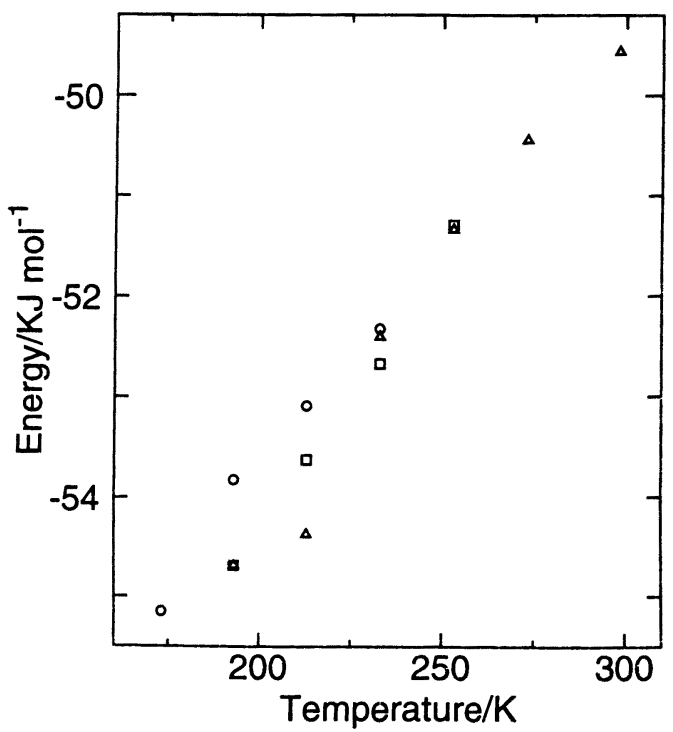

図2 調和振動の $3 R T$ を差し引いたポテンシャルエネルギ 一. 三角; 圧力 $p=0.1 \mathrm{MPa}$, 丸 ; 圧力 $p=+200 \mathrm{MPa}$, 四角; 圧力 $p=-200 \mathrm{MPa}$.

る同様なプロットを図 3 に示す，大気圧でも高圧でもポ テンシャルエネルギーに不連続が現れた温度において密 度の不連続もあることが分かる．またこの位置は実験に よる $T_{s}$ と比較すると $15 \mathrm{~K}$ 程低温であるが, 密度が最大 である温度も同程度にシフトしていることから； $213 \mathrm{~K}$ 付近の不連続が $T_{\mathrm{s}}$ に対応していることを示している.ポ テンシャルエネルギーの場合とは異なり, 高圧では密度
の不連続性は大きくなる，一方，負の圧力では密度の温 度依存性は見られない。

以上の結果は, 高圧から大気圧までは異なる二相の液 体があり, 高温側では高密度相また低温側では低密度相 が安定であることを意味している，通常の液体では単一 相しか存在せず，しかも密度と温度の関係が逆である. LDA は氷よりも $1 \mathrm{~kJ} / \mathrm{mol}$ エネルギーが高いだけであり， この差は Normal Water と LDAの差 $1.5 \mathrm{~kJ} / \mathrm{mol}$ よりも小 さい.また相平衡を仮定した自由エネルギーの計算から LDA は氷よりわずかにエントロピーが大きい状態であ り，過冷却の水と比べてこれまで想像されていた以上に 水素結合の欠陥が少ないものと予想される．事実，シミ ユレーションから得られた水素結合数の分布に非常に大 きな差が見られる（表 1 ). 氷では 1 分子の水は周囲 4 分子と強く水素結合している，液体の水でも室温以下で は水素結合はほとんど残っていることが水と他の液体と の差を際立たせる原因であるが，この Normal Waterで は完全な水素結合をしている水は $84 \%$ 程度である。一

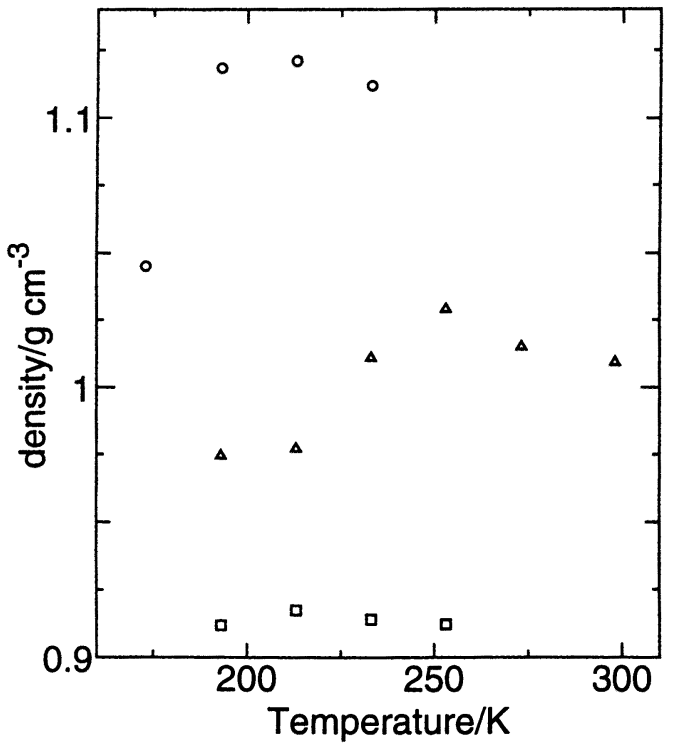

図 3 水の密度. 三角; 圧力 $p=0.1 \mathrm{MPa}$, 丸 ; 圧力 $p=+$ $200 \mathrm{MPa}$, 四角; 圧力 $p=-200 \mathrm{MPa}$.

表 1 水素結合数分布。水素結合エネルギーはー $12 \mathrm{kJmol}^{-1}$ 以下.

\begin{tabular}{cccccc}
\hline \hline$T$ & 1 & 2 & 3 & 4 & 5 \\
\hline 298 & 0 & 0.008 & 0.145 & 0.776 & 0.070 \\
233 & 0 & 0.005 & 0.101 & 0.838 & 0.055 \\
213 & 0.0 & 0.001 & 0.040 & 0.939 & 0.020 \\
193 & 0.0 & 0.001 & 0.041 & 0.934 & 0.023 \\
\hline \hline
\end{tabular}


方, $213 \mathrm{~K}$ 以下の LDA では $10 \%$ も増えて, 水素結合の 欠陥は極端に減少している。

最後に, 液液の相平衡は水に限られた現象ではなく, 三次元ネットワークを形成する $\mathrm{Si}, \mathrm{Ge}$ や $\mathrm{SiO}_{2}$ などでは 実験的にも観測されることもあることを付け加えておく (Angell, 1995)。これらの物質は結晶では 4 面体構造をと り，エネルギーは低いが空間充填率は低いという共通の 特徵を有する。また，このような低温での水溶液の物性 の研究は, 細胞の低温での結晶化による破壊からの防御 機構や, 低温での食品の保存方法の開発という生物学や 工学などとの関連からも重要となるであろう.

\section{文献}

Angell, C. A., 1995: Formation of Glasses from Liquids and Biopolymers. Science, 267, 1924-1935.

河村雄行, 1996 : 水に関する最近の分子動力学シミュレー ション.雪水, $\mathbf{5 8}, 339-342$.

Ohmine, I and Tanaka, H., 1993: Fluctuation, Relaxations, and Hydration in Liquid Water. Hydrogen-Bond Rearrangement Dynamics. Chem. Rev. 93, 2545-2566.

Poole, P.H., Sciortino, F., Essmann, U., Stanley, H.E., 1992: Phase behaviour of metastable water. Nature, 360, 324328.

Tanaka, H., 1996 a: A self-consistent phase diagram for supercooled water. Nature, 380, 328-330.

Tanaka, H., 1996 b: Phase behaviors of supercooled water: Reconciling a critical point of amorphous ices with spinodal instability. J. Chem. Phys. 105, 5099-5111.

(1997 年 3 月 6 日受付) 